\title{
Is it so definite that the dental procedure is the only treatment, which requires prophylaxis???
}

\author{
Hande Yesil ${ }^{1}$, Ozgur Ozturk ${ }^{1}$, Nurten Baysal ${ }^{1}$, Fahri Gurkan Yesil ${ }^{2}$, Mustafa Kurkluoglu $^{3}$, Sevket Balta ${ }^{4}$, \\ Mehmet Ali Sahin ${ }^{2}$ \\ ${ }^{1}$ Department of Prosthodontics, Gulhane Medical Academy Ankara, Turkey \\ ${ }^{2}$ Department of Cardiovascular Surgery, Gulhane Medical Academy Ankara, Turkey \\ ${ }^{3}$ Department of Cardiovascular Surgery, Children's National Heart Institute, Children's National Medical Center, \\ Washington, DC, USA \\ ${ }^{4}$ Department of Cardiology, Gulhane Medical Academy Ankara, Turkey \\ Kardiochirurgia i Torakochirurgia Polska 2013; 10 (1): 93-94
}

\section{Dear Editor,}

We read the article "Current level of infective endocarditis prevention awareness among dentists and patients with artificial valves" by Pawlus et al. with interest [1]. They investigated infective endocarditis (IE) prevention awareness among dentists and patients with artificial heart valves. They demonstrated that almost all dentists indicated the need for dental IE prophylaxis for patients with artificial valves. They also report that most of the patients with artificial heart valves were aware of IE prophylaxis before dental procedures and about one third of the patients indicated the need for IE prophylaxis prior to invasive procedures other than dental care, in a patient with an artificial valve. We thank the authors for their enlightening analysis and we would like to contribute.

Pawlus et al. report in their study [1] that currently the only treatments that require IE prophylaxis are dental procedures. But, is it really so definite that dental procedures are the only treatments which require prophylaxis? The main pathology that requires prophylaxis for the prevention of IE is the presence of bacteremia [2]. Although the risk of bacteremia associated with dental procedures is higher than that for surgical intervention on the mucous membranes of the genitourinary system and gastrointestinal tract [3], the potential risk of transient bacteremia does not just follow dental procedures but also may occur after routine interventional procedures such as bronchoscopy and colonoscopy, and even after routine daily activities like tooth brushing. There are conflicting reports as to the significance of bacteremia caused by these interventional procedures in current clinical guidelines [4]. In addition, American Heart Association guidelines report that, "in high-risk patients with infections of the gastrointestinal or genitourinary tract, it is reasonable to administer antibiotic therapy to prevent wound infection or sepsis" [5]. Therefore, those clinicians concerned with infective endocarditis should keep in mind that some interventional procedures may lead to bacteremia changing in magnitude. Because of the bacteremia, some interventions other than dental procedures may require IE prophylaxis regarding patient conditions.

A second point that we want to make concerns fungal infections and their prophylaxis. Bacterial infections are not the only etiological substrate for IE. Fungal infections also carry great importance for the etiology of IE [6]. Therefore, the early diagnosis of fungal endocarditis through heightened diagnostic acumen is so vital and amphotericin B is a good option for these situations [6].

There is no conflict of interests.

\section{References}

1. Pawlus B, Markowicz-Pawlus E, Špidlen M. Current level of infective endocarditis prevention awareness among dentists and patients with artificial valves. Kardiochirur Torakochirur Pol 2012; 10: 2-5.

2. Ostrowski S, Nowak D, Marcinkiewicz A, Kasielski M, Zwoliński R, Jaszewski R. Assessment of the surgical treatment of patients with infective endocarditis through observation of alterations in selected inflammatory markers in the postoperative period. Kardiochirur Torakochirur Pol 2011; 8: 183-190.

3. Bielacz M, Kosek-Hoehne K, Hoehne D, Pawlak S, Janda A. Effect of periodontal diseases on the development of infective endocarditis. Kardiochirur Torakochirur Pol 2011; 8: 394-398.

4. Centre for Clinical Practice at NICE (UK). Prophylaxis against infective endocarditis Antimicrobial prophylaxis against infective endocarditis in adults and children undergoing interventional procedures. NICE Clinical Guidelines, No. 64. 2008.

5. Nishimura RA, Carabello BA, Faxon DP, Freed MD, Lytle BW, O'Gara PT, O'Rourke RA, Shah PM, Bonow RO, Carabello BA, Chatterjee K, de Leon AC Jr, Faxon DP, Freed MD, Gaasch WH, Lytle BW, Nishimura RA, O'Gara PT, O'Rourke RA, Otto CM, Shah PM, Shanewise JS, Smith SC Jr, Jacobs AK, Buller CE, Creager MA, Ettinger SM, Krumholz HM, Kushner FG, Lytle BW,

Address for correspondence: Fahri Gurkan Yesil, MD, Gulhane School of Medicine, Department of Cardiovascular Surgery, Tevfik Saglam St., 06018 Etlik-Ankara, Turkey, tel. +90 312 3045271, fax +90 312 3044250, e-mail: fahrigurkanyesil@gmail.com 
Nishimura RA, Page RL, Tarkington LG, Yancy CW Jr; American College of Cardiology/American Heart Association Task Force. ACC/AHA 2008 guideline update on valvular heart disease: focused update on infective endocarditis: a report of the American College of Cardiology/American Heart Association Task Force on Practice Guidelines: endorsed by the Society of Cardiovascular Anesthesiologists, Society for Cardiovascular Angiography and Interventions, and Society of Thoracic Surgeons. Circulation 2008; 118: 887-896.

6. Ellis ME, Al-Abdely H, Sandridge A, Greer W, Ventura W. Fungal endocarditis: evidence in the world literature, 1965-1995. Clinical infectious diseases. Clin Infect Dis 2001; 32: 50-62. 